\title{
Relationship between Organizational Culture with Efficiency of Directors in Islamic Azad University Branch of Shahr-E-Qods
}

Arezo Ahmadi Danyali*

Assistant Professor, Department of Business, Faculty of Management, Shahre Ghods Science and Research Branch, Islamic Azad University, Iran

\begin{abstract}
Today, desirable organization culture is one of the aspects of power and distinction among organizations. Organizational culture in each body fully reflects specifications, properties, powers and weaknesses in that organization reflecting its inside and outside characteristics in terms of director's commitment to values, principles, beliefs, attitudes and other related options. Thinkers believe that in the same manner men has unique and distinguished personality, organizations, as well, have unparalleled personality for their culture which determines the necessity to identify organizations culture. Organizational culture is considered to be a descriptive term and the authorities and scientists believe descriptive study of dimensions of such indicator in identification of culture. Brief study of the country universities indicates that organizational culture suitable for training and research is found to limited extent in the said centers. Such factors made the researcher to perform an effective research with efficiency component in order to identify the organizational culture governing the organization.
\end{abstract}

Keywords: Organizational culture; Productivity; Director's commitment; Performance; Distinguished personality

\section{Introduction}

Now a days productivity and efficiency have the most valuable place by managers. Managers are searching for more efficiency and effectivity and their efforts are made to the same direction in order to establish organization consistency in this competitive world. Robert Queen says on the subject that identification of the culture is a very important and essential step in identification of organizations and staff behavior and performance for changes are facilitated and new attitudes are stabilized in the organization easily with the use of culture.

So organization culture is an important factor in organization success and fulfillment of its long term objectives.

Leadership is critical in codifying and maintaining an organization's purpose, values, and vision. Leaders must set the example by living the elements of culture: values, behaviors, measures, and actions. Values are meaningless without the other element, such that organizations with clearly codified and enforced cultures enjoy great employee and customer loyalty. Like anything worthwhile, corporate culture is something in which you invest. An organization's norms and values aren't formed through speeches but through actions and team learning. Leadership is a process by which a person influences others (followers) to accomplish an objective and directs the organization in a way that makes it more cohesive and coherent. Leaders carry out this process by applying their leadership attributes, such as beliefs, values, ethics, character, knowledge, and skills. Underlying this ability are fundamental executive processes, or meta-components [1] recognizing the existence of a problem, defining and redefining the problem, allocating resources to the solution of the problem, representing the problem mentally, formulating a strategy for solving the problem, monitoring the solution of the problem while problem solving is ongoing, and evaluating the solution to the problem after it has been solved. Creative intelligence is involved when one applies the processes to relatively novel tasks and situations.

Organizational cultures are much more than slogans and empty promises. Some organizations choose to part ways with those who do not manage according to the values and behaviors that other employees embrace. Others accomplish the same objective more positively.
Employees at all levels in an organization notice and validate the elements of culture. As owners, they judge every management decision to hire, reward, promote, and fire colleagues [2].

The most important idea of all major companies like GM, IBM, and Sears is that those pushing for organizational improvement--whether they are external members of the board, major investors, or top executives--must deal with cultural and behavioral obstacles to change. Specifically, attempts at organizational change must consider three key features of organizational life: the firm's culture, the leadership of the change effort, and the existing network of power.

An organization's culture has a substantial impact on its ability to execute its strategy and to achieve business goals and objectives. If a culture and work environment are cultivated intentionally, it improves dramatically an organization's ability to execute, and they often become better places to work. They become well known among prospective employees. The level of ownership-referral rates and ideas for improving the business of existing employees is often high. The screening process is simplified, because employees tend to refer acquaintances who behave like them. The pool of prospective employees grows. The cost of selecting among many applicants is offset by cost savings as prospective employees sort themselves into and out of consideration for jobs. This self-selection process reduces the number of mismatches among new hires. Members of an organization soon come to sense the particular culture of an organization. Organizational culture facilitates the acceptable solutions for knowing the problems, which members learn, feel and set the principles, expectations, behavior, patterns, and norms that promote a high level of achievement [3].

*Corresponding author: Arezo Ahmadi Danyali, Assistant Professor, Department of Business, Faculty of Management, Shahre Ghods Science and Research Branch, Islamic Azad University, Iran, Tel: +982147911; E-mail: rzdanyali@gmail.com

Received August 05, 2014; Accepted December 22, 2014; Published December 24, 2014

Citation: Danyali AA (2014) Relationship between Organizational Culture with Efficiency of Directors in Islamic Azad University Branch of Shahr-E-Qods. Review Pub Administration Manag 2: 145. doi:10.4172/2315-7844.1000145

Copyright: @ 2014 Danyali AA. This is an open-access article distributed under the terms of the Creative Commons Attribution License, which permits unrestricted use, distribution, and reproduction in any medium, provided the original author and source are credited. 
Citation: Danyali AA (2014) Relationship between Organizational Culture with Efficiency of Directors in Islamic Azad University Branch of Shahr-EQods. Review Pub Administration Manag 2: 145. doi:10.4172/2315-7844.1000145

Page 2 of 5

What is the significance of highlighting these "obvious" complexities and potential conflicts within a corporate culture? Put quite simply - organizational designs are culturally-bound paradigms for solutions; they are operations of cultural frames of reference that determine how problems are solved and relationships defined [4]; they guide strategy for organizational development. Essentially, principles associated with a specific design become norms that influence employee actions and represent defining features of that organization's culture. So, identifying a predisposition for solving problems, i.e., an organizational design, contributes to an increased appreciation and understanding of organizational culture.

It has been established that satisfying the specific job requirements on a day-to-day basis through on-the-job task performance is not the only important component of employee effectiveness $[1,5,6]$. Many people feel like they have little stake in the place they work, because they don't understand the goals and strategies of the business, and when they do seek out this information they get the run around. We don't know if most management teams are intentionally indirect about how their strategies and goals function, but it can be embarrassing for some of them to map-out what teams are asked to do back to corporate goals and strategies. True, many senior managers are very vague in their communications. Perhaps they don't want to be held accountable, or perhaps they just don't have a strategy, and are uncertain about how the business is run. Quite often, people claim ignorance or don't want to acknowledge a corporate strategy. This important assumption, that culture drives employee behaviors, however, has received only limited direct empirical attention [7].

Because of unreasonably high performance expectations, competitive behavior taken to an unethical level became the norm for many Enron managers and employees. The Enron leadership sustained this aggressive culture by enriching themselves, possibly unethically. By comparison, companies prominent for their innovation competencies like $3 \mathrm{M}$ and Apple effectively reinforce innovative employee behavior by sustaining a culture of creativity and innovation [8]. Each of these aspects has its own role in defining what the organizational culture will be. Organizational culture is basically a system of shared beliefs that members of the organization have. This determines how members in an organization act when confronted with decision-making responsibilities. In every organization, you will notice that there are systems or patterns of values that are constantly evolving.

Recent events in the business world nevertheless suggest that understanding organizational culture and its impact on human behavior in organizations may be of critical importance. Enron, for instance, is an exemplar of how having the wrong organizational culture precipitates business failure. Enron's high achievement oriented, entrepreneurial employees reinforced the competitive "survival-of-the-fittest" culture of the company [9].

In the present work, researcher tries to give the required recommendations for improvement of the conditions and performance by defining the relation between organization culture and the ten factors with the given society productivity. Researcher hope that findings in this research work may be helpful for managers in Islamic Azad University of Shahr-e-Qods in planning, effective guidance and improvement of university organization and would also facilitate the possibility to fulfill their organization objectives.

\section{Research Objectives}

- Study of creativity as organization culture factor and its relation with managers' productivity
- Study the relation between managers risk taking with efficiency

- $\quad$ Study the relation between leadership in organization with managers efficiency

- Determine the relationship between managerial support and employees efficiency in the organization

- Determine the factor of coordination and harmony and its relation with managers' efficiency

- Determine organization identity and its relation with manager's efficiency

- Study the relation between reward in organization and its connection with managers' efficiency

- $\quad$ Study the relation between reconciliation with inconsistency and its connection with manager's efficiency

- Determine communication pattern and its relation with manager's efficiency

- Study organizational control and supervision and its relation with manager's efficiency

\section{Research Method}

This is an applied research, classified as descriptive and survey work form specialty viewpoint and is executed periodically in 8 month span. Combination of field and library method is used in this research.

\section{Statistical Community}

Statistical community is consisted from managers and senior employees in Islamic Azad University, Shahr-e-Qods Campus.

\section{Research Limitations}

- Limited sources was the main problem in this research work

- Obtaining license from connected centers required much time to be spent

- Research objective was unknown for supervisors in some centers and they were unfamiliar with benefits from similar researches

- No information about the importance and value of researches by responders

- Subjects anxiety in responding, when completing the questionnaires in some cases

- Uncontrolled intervening alternatives which may be effective on results

\section{Conclusions}

Conclusions from individual characteristics of sample group

Individual characteristics of sample group were defined as following:

- Research findings indicate that $50 \%$ of the sample group was 31 to 35 years and $13.3 \%$ was 30 years old and younger (Figure1).

- $\quad$ Research findings indicate that $20 \%$ of the subjects (lowest) had bachelor degree while $50 \%$ of the subjects (highest) had doctorate degree or PhD students (Figure 2).

- $\quad$ Research findings indicate that $53.3 \%$ of subjects (highest) were working in the field of education while $10 \%$ of the subjects 
Citation: Danyali AA (2014) Relationship between Organizational Culture with Efficiency of Directors in Islamic Azad University Branch of Shahr-EQods. Review Pub Administration Manag 2: 145. doi:10.4172/2315-7844.1000145

Page 3 of 5

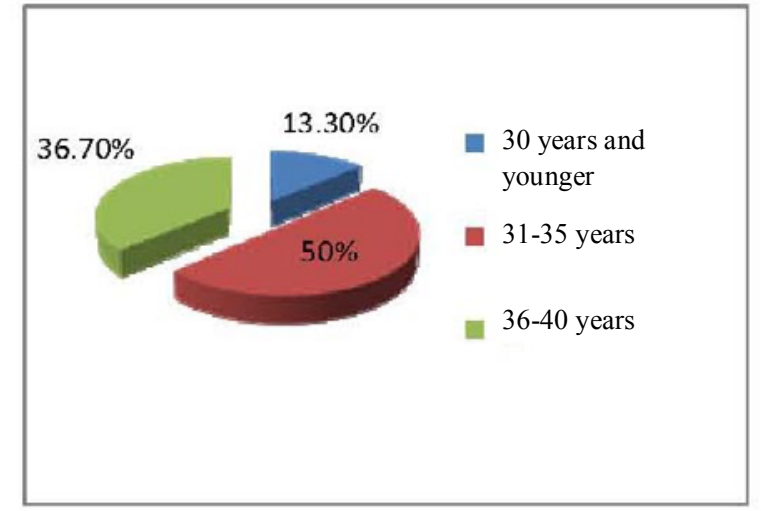

Figure 1: Frequency of sample subjects on the basis of age.

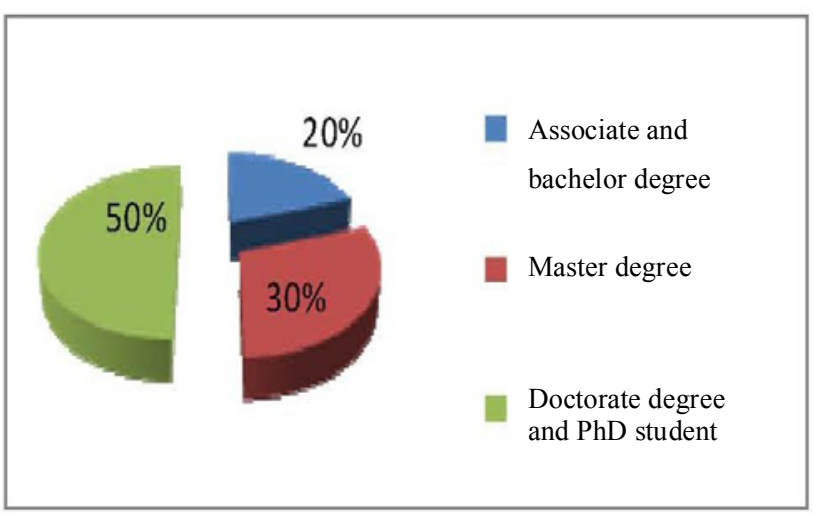

Figure 2: Pie chart for the sample group subjects on the basis of education.

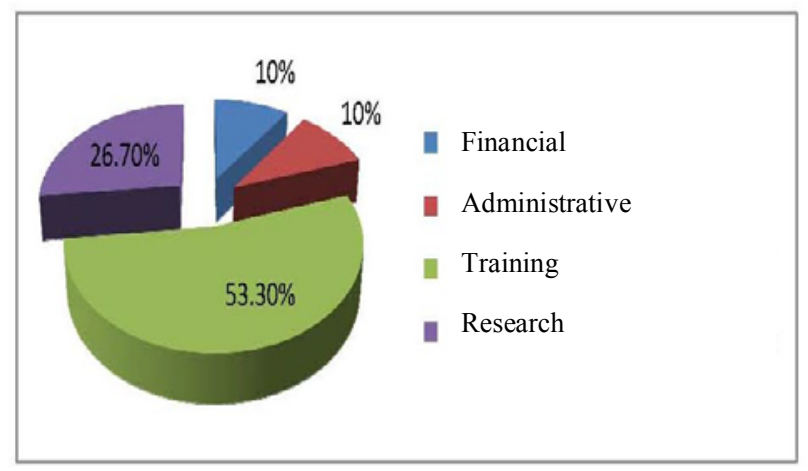

Figure 3: Pie chart for the sample group subjects on the basis of the field of activity.

(lowest) were working in financial and administrative fields (Figure 3).

- Research findings indicate that $63.3 \%$ of the subjects (highest) were male and 36. 7\% (lowest) were female (Figure 4).

- $\quad$ Research findings indicate that $60 \%$ of the subjects (highest) had 5 to 8 years of service while $10 \%$ (lowest) had 1 to 4 years of service (Figure 5).

- $\quad$ Research findings indicate that $40 \%$ of the subjects (highest) had contractual employment status while $30 \%$ of the subjects (lowest) had salaried employment status (Figure 6).

\section{Study of Research Questions}

- $\quad$ Research findings indicate that whereas the test significance $(p=0.015)$ was smaller than the test alpha quantity $(0.05)$, therefore research question is verified. As the result, there is significant relation between efficiency and organization identity (Table 1).

As well considering that correlation coefficient between the two alternatives is 0.44 , the significant relation is concluded to be positive. In other word, efficiency would increase with organization identity.

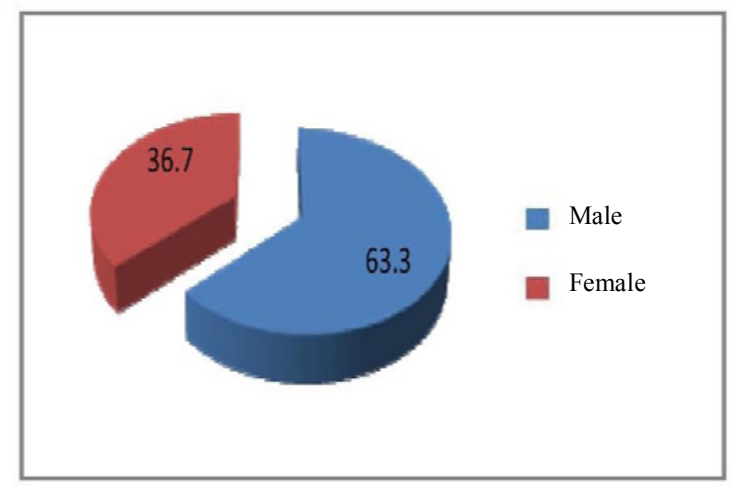

Figure 4: Pie chart for the sample group subjects on the basis of sex.

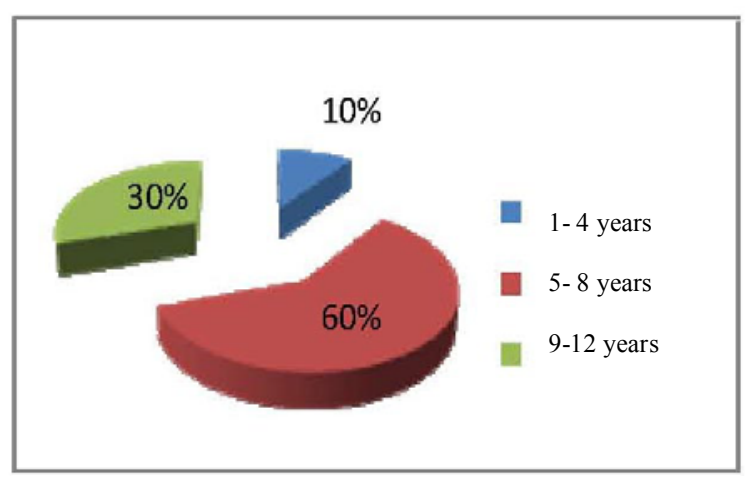

Figure 5: Pie chart for the sample group subjects on the basis of work record.

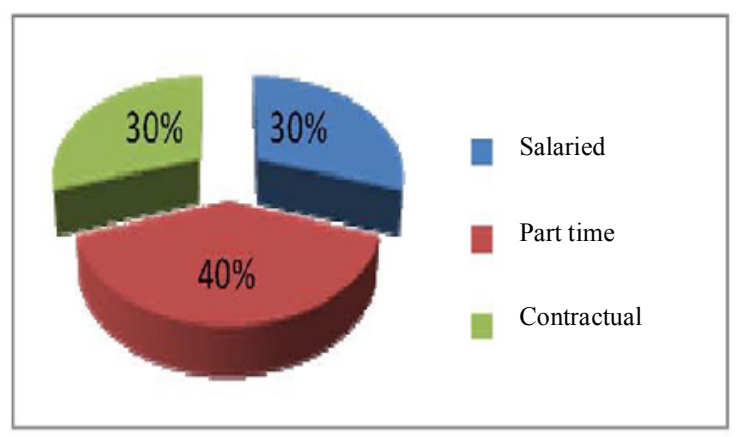

Figure 6: Pie chart for the sample group subjects based on employment status. 
Citation: Danyali AA (2014) Relationship between Organizational Culture with Efficiency of Directors in Islamic Azad University Branch of Shahr-EQods. Review Pub Administration Manag 2: 145. doi:10.4172/2315-7844.1000145

Page 4 of 5

\begin{tabular}{|l|l|l|l|l|l|}
\hline Alternatives & $\begin{array}{l}\text { Sample } \\
\text { size }\end{array}$ & Average & $\begin{array}{l}\text { Standard } \\
\text { deviation }\end{array}$ & $\begin{array}{l}\text { Correlation } \\
\text { Coefficient }\end{array}$ & $\begin{array}{l}\text { Significance } \\
\text { level (p) }\end{array}$ \\
\hline Efficiency & 30 & 3.97 & 0.47 & 0.440 & 0.015 \\
\hline $\begin{array}{l}\text { Organization } \\
\text { identity }\end{array}$ & 30 & 3.54 & 0.47 & & \\
\hline
\end{tabular}

Is there significant relation between efficiency and organization identity?

Table 1: Comparative table for efficiency and organization identity.

\begin{tabular}{|l|l|l|l|l|l|}
\hline Alternatives & $\begin{array}{l}\text { Sample } \\
\text { size }\end{array}$ & Average & $\begin{array}{l}\text { Standard } \\
\text { deviation }\end{array}$ & $\begin{array}{l}\text { Correlation } \\
\text { Coefficient }\end{array}$ & $\begin{array}{l}\text { Significance } \\
\text { level (p) }\end{array}$ \\
\hline Efficiency & 30 & 3.54 & 0.476 & 0.542 & 0.002 \\
\hline Risk taking & 30 & 2.92 & 0.756 & & \\
\hline
\end{tabular}

Is there significant relation between efficiency and risk taking?

Table 2: Comparative table for efficiency and risk taking.

\begin{tabular}{|l|l|l|l|l|l|}
\hline Alternatives & $\begin{array}{l}\text { Sample } \\
\text { size }\end{array}$ & Average & $\begin{array}{l}\text { Standard } \\
\text { deviation }\end{array}$ & $\begin{array}{l}\text { Correlation } \\
\text { Coefficient }\end{array}$ & $\begin{array}{l}\text { Significance } \\
\text { level (p) }\end{array}$ \\
\hline Efficiency & 30 & 3.545 & 0.476 & 0.546 & 0.002 \\
\hline $\begin{array}{l}\text { Communication } \\
\text { pattern }\end{array}$ & 30 & 3.50 & 0.601 & & \\
\hline
\end{tabular}

Is there significant relation between efficiency and communication pattern?

Table 3: Comparative table for efficiency and communication pattern.

\begin{tabular}{|l|l|l|l|l|l|}
\hline Alternatives & $\begin{array}{l}\text { Sample } \\
\text { size }\end{array}$ & Average & $\begin{array}{l}\text { Standard } \\
\text { deviation }\end{array}$ & $\begin{array}{l}\text { Correlation } \\
\text { Coefficient }\end{array}$ & $\begin{array}{l}\text { Significance } \\
\text { level (p) }\end{array}$ \\
\hline Efficiency & 30 & 3.54 & 0.476 & 0.571 & 0.001 \\
\hline $\begin{array}{l}\text { Organization } \\
\text { integration }\end{array}$ & 30 & 3.27 & 0.689 & & \\
\hline
\end{tabular}

Is there significant relation between efficiency and organization integration?

Table 4: Comparative table for efficiency and organization integration.

- $\quad$ Research findings indicate that whereas the test significance $(\mathrm{p}=0.002)$ was smaller than the test alpha quantity $(0.05)$, therefore research question is verified. As the result, there is significant relation between efficiency and risk taking and vice versa (Table 2).

As well considering that correlation coefficient between the two alternatives is 0.542 , the significant relation is concluded to be positive. In other word, efficiency would increase with risk taking and vice versa.

- Research findings indicate that whereas the test significance $(\mathrm{p}=0.002)$ was smaller than the test alpha quantity $(0.05)$, therefore research question is verified. As the result, there is significant relation between efficiency and communication pattern (Table 3 ).

As well considering that correlation coefficient between the two alternatives is 0.546 , the significant relation is concluded to be positive. In other word, efficiency would increase with communication pattern and vice versa.

- $\quad$ Research findings indicate that whereas the test significance $(p=0.001)$ was smaller than the test alpha quantity $(0.05)$, therefore research question is verified. As the result, there is significant relation between efficiency and organization integration (Table 4).

As well considering that correlation coefficient between the two alternatives is 0.571 , the significant relation is concluded to be positive. In other word, efficiency would increase with organization integration and vice versa.

- $\quad$ Research findings indicate that whereas the test significance ( $\mathrm{p}=0.001)$ was smaller than the test alpha quantity $(0.05)$, therefore research question is verified. As the result, there is significant relation between efficiency and management support (Table 5).
As well considering that correlation coefficient between the two alternatives is 0.651 , the significant relation is concluded to be positive. In other word, efficiency would increase with management support and vice versa.

- Research findings indicate that whereas the test significance ( $\mathrm{p}=0.002$ ) was smaller than the test alpha quantity $(0.05)$, therefore research question is verified. As the result, there is significant relation between efficiency and organization control or supervision (Table 6).

As well considering that correlation coefficient between the two alternatives is 0.538 , the significant relation is concluded to be positive. In other word, efficiency would increase with organization control or supervision and vice versa.

- Research findings indicate that whereas the test significance $(\mathrm{p}=0.001)$ was smaller than the test alpha quantity $(0.05)$, therefore research question is verified. As the result, there is significant relation between efficiency and individual creativity (Table 7).

As well considering that correlation coefficient between the two alternatives is 0.576 , the significant relation is concluded to be positive. In other word, efficiency would increase with individual creativity and vice versa.

- Research findings indicate that whereas the test significance $(p=0.021)$ was smaller than the test alpha quantity $(0.05)$, therefore research question is verified. As the result, there is significant relation between efficiency and reward (Table 8).

\begin{tabular}{|l|l|l|l|l|l|}
\hline Alternatives & $\begin{array}{l}\text { Sample } \\
\text { size }\end{array}$ & Average & $\begin{array}{l}\text { Standard } \\
\text { deviation }\end{array}$ & $\begin{array}{l}\text { Correlation } \\
\text { Coefficient }\end{array}$ & $\begin{array}{l}\text { Significance } \\
\text { level (p) }\end{array}$ \\
\hline Efficiency & 30 & 3.54 & 0.476 & 0.651 & 0.001 \\
\hline $\begin{array}{l}\text { Management } \\
\text { support }\end{array}$ & 30 & 3.60 & 0.680 & & \\
\hline
\end{tabular}

Is there significant relation between efficiency and management support?

Table 5: Comparative table for efficiency and management support.

\begin{tabular}{|l|l|l|l|l|l|}
\hline Alternatives & $\begin{array}{l}\text { Sample } \\
\text { size }\end{array}$ & Average & $\begin{array}{l}\text { Standard } \\
\text { deviation }\end{array}$ & $\begin{array}{l}\text { Correlation } \\
\text { Coefficient }\end{array}$ & $\begin{array}{l}\text { Significance } \\
\text { level (p) }\end{array}$ \\
\hline Efficiency & 30 & 3.54 & 0.476 & 0.538 & 0.002 \\
\hline $\begin{array}{l}\text { Organization } \\
\text { control and } \\
\text { supervision }\end{array}$ & & & & & \\
\hline
\end{tabular}

Is there significant relation between efficiency and organization control or supervision?

Table 6: Comparative table for efficiency and organization control and supervision.

\begin{tabular}{|l|l|l|l|l|l|}
\hline Alternatives & $\begin{array}{l}\text { Sample } \\
\text { size }\end{array}$ & Average & $\begin{array}{l}\text { Standard } \\
\text { deviation }\end{array}$ & $\begin{array}{l}\text { Correlation } \\
\text { Coefficient }\end{array}$ & $\begin{array}{l}\text { Significance } \\
\text { level (p) }\end{array}$ \\
\hline Efficiency & 30 & 3.54 & 0.476 & 0.576 & 0.001 \\
\hline $\begin{array}{l}\text { Individual } \\
\text { creativity }\end{array}$ & 30 & 3.60 & 0.824 & & \\
\hline
\end{tabular}

Is there significant relation between efficiency and individual creativity?

Table 7: Comparative table for efficiency and individual creativity.

\begin{tabular}{|l|l|l|l|l|l|}
\hline Alternatives & $\begin{array}{l}\text { Sample } \\
\text { size }\end{array}$ & Average & $\begin{array}{l}\text { Standard } \\
\text { deviation }\end{array}$ & $\begin{array}{l}\text { Correlation } \\
\text { Coefficient }\end{array}$ & $\begin{array}{l}\text { Significance } \\
\text { level (p) }\end{array}$ \\
\hline Efficiency & 30 & 3.54 & 0.476 & 0.654 & 0.021 \\
\hline Reward & 30 & 3.18 & 0.675 & & \\
\hline
\end{tabular}

Is there significant relation between efficiency and reward?

Table 8: Comparative table for efficiency and reward. 
Citation: Danyali AA (2014) Relationship between Organizational Culture with Efficiency of Directors in Islamic Azad University Branch of Shahr-EQods. Review Pub Administration Manag 2: 145. doi:10.4172/2315-7844.1000145

\begin{tabular}{|l|l|l|l|l|l|}
\hline Alternatives & $\begin{array}{l}\text { Sample } \\
\text { size }\end{array}$ & Average & $\begin{array}{l}\text { Standard } \\
\text { deviation }\end{array}$ & $\begin{array}{l}\text { Correlation } \\
\text { Coefficient }\end{array}$ & $\begin{array}{l}\text { Significance } \\
\text { level (p) }\end{array}$ \\
\hline Efficiency & 30 & 3.54 & 0.476 & 0.680 & 0.037 \\
\hline Inconsistency & 30 & 3.18 & 0.675 & & \\
\hline
\end{tabular}

Is there significant relation between efficiency and inconsistency?

Table 9: Comparative table for efficiency and inconsistency.

\begin{tabular}{|l|l|l|l|l|l|}
\hline Alternatives & $\begin{array}{l}\text { Sample } \\
\text { size }\end{array}$ & Average & $\begin{array}{l}\text { Standard } \\
\text { deviation }\end{array}$ & $\begin{array}{l}\text { Correlation } \\
\text { Coefficient }\end{array}$ & $\begin{array}{l}\text { Significance } \\
\text { level (p) }\end{array}$ \\
\hline Efficiency & 30 & 3.54 & 0.476 & 0.757 & 0.001 \\
\hline Leadership & 30 & 3.51 & 0.793 & & \\
\hline
\end{tabular}

Is there significant relation between efficiency and leadership?

Table 10: Comparative table for efficiency and leadership.

As well considering that correlation coefficient between the two alternatives is 0.654 , the significant relation is concluded to be positive. In other word, efficiency would increase with rewards and encouragements and vice versa.

- $\quad$ Research findings indicate that whereas the test significance ( $p=0.037)$ was smaller than the test alpha quantity $(0.05)$, therefore research question is verified. As the result, there is significant relation between efficiency and inconsistency (Table 9).

As well considering that correlation coefficient between the two alternatives is 0.68 , the significant relation is concluded to be positive. In other word, efficiency would increase with inconsistency and vice versa.

- $\quad$ Research findings indicate that whereas the test significance $(p=0.001)$ was smaller than the test alpha quantity $(0.05)$, therefore research question is verified. As the result, there is significant relation between efficiency and leadership (Table 10).

As well considering that correlation coefficient between the two alternatives is 0.757 , the significant relation is concluded to be positive. In other word, efficiency would increase with leadership and vice versa.

Analysis of findings indicate that there is significant relation between organization culture with managers efficiency in Islamic Azad University, Shahr-e-Qods Campus.

\section{References}

1. Sternberg RJ (1985) Beyond IQ: A Triarchic theory of human intelligence; Cambridge University Press, New York.

2. Borman WC, Motowidlo SJ, Schmitt N, Borman W (1993) Expanding the criterion domain to include elements of contextual New York: performance. Personnel selection in organizations; Jossey-Bass, New York: 71-98.

3. Marcoulides G, Heck RH (1993) Organizational Culture and Performance. Proposing and Testing a Model, Organizational Science 4: 209-223.

4. Trompenaars F (1993) Riding the waves of culture: Understanding cultura diversity in business; Bath Press, Great Britain.

5. Organ DW (1988) Organizational Citizenship Behavior: The good soldier síndrome; Lexington Books, Lexington.

6. Van Scotter J, Motowidlo S (1996) Interpersonal facilitation and job dedication as separate facets of contextual performance. Journal of Applied Psychology 81: $525-531$.

7. Tesluk P, Hofmann D, Quigley N (2002) Integrating the linkages between organizational culture and individual outcomes at work, Psychological Management of Individual Performance; John Wiley and Sons.

8. Tesluk PE, Farr JL, Klein SR (1997) Influences of organizational culture and climate on individual creativity. Journal of Creative Behavior 31: 27-41.

9. Fathi El.Nadi (2008) Reflections on management and Human Resources aspects based on both academic and field experience multi. 